\title{
Adsorption kinetic models of heavy metal ions on granular activated carbon
}

\begin{abstract}
Adsorption is considered as one of the most effective and cost efficient methods in water effluents purification. Frequently used adsorbent for heavy metals removal is activated carbon. The adsorption of lead ions from wastewater model solutions on activated carbon has been studied by a batch adsorber. Experiments were performed at constant temperature, while the concentration of lead ions in the solutions has been varied.

Using the MatLab software the parameters for the Langmuir and Freundlich adsorption isotherms were determined. The experimental data obeys the Langmuir isotherm, and the maximum sorption capacity determined was $17.09 \mathrm{mg} \mathrm{g}^{-1}$. The impact of the quantity of activated carbon and the initial concentration of lead ion on adsorption kinetics has been studied. The kinetics models for the first, pseudo-first, second and pseudo-second-order reaction were fitted to the experimentally obtained data by MatLab software. Data obtained by the kinetics study of $\mathrm{Pb}^{2+}$ adsorption on activated carbon, might be useful in the selection of the most probable mechanism of the adsorption process. It has been shown that the pseudo-second-order model explains the experimental data the best.
\end{abstract}

Key words: adsorption, lead sorption, adsorption isotherms, kinetics

\section{INTRODUCTION}

As the result of the industrial expansion we are faced with the increased amount of both, inorganic and organic pollutants in the waste water that represent a serious threat for the human health. Among many contaminants, heavy metals are those which attract bigger attention. Namely, it is considered that particularly the presence of lead, cadmium, mercury and arsenic in the eco-system has a tremendous adverse impact to the human health. So, the exposure to these heavy metals exceeding the limits directed by the European directives and local legislation, could initiate mild and moderate disorders of the tissues' functionality, but also the severe illnesses, such as kidney damage, thyroid dysfunctions, degeneration of motor neurons, mental retardation, birth defects and/or occurrence of some types of cancer [1]. Furthermore, an intellectual discrepancy in children has been associated to the exposure of small dosage of lead, but the higher lead concentrations could stimulate more serious damages, even death [2].

A lot of techniques, e.g. filtration, ion exchange, chemical precipitation, reverse osmosis, etc., have been developed in the waste water treatment, but in some cases they cannot provide successful

Author address: International Balkan University, Faculty of Engineering, Tashko Karadza, 11A, Skopje, R. Macedonia

Paper received: 04. 02. 2015.

Paper accepted: 25. 03. 2015. removal of the ions or their application is very expensive. Thus, adsorption, as a simple, adaptable, and low cost method is considered to be a convenient route in the control of the water effluence [1], especially handling low concentration waste streams and meeting severe treatment levels [3].

Wide range of adsorbents, such as zeolites, clay, biomaterials, industrial or agricultural wastes, etc., considered as inexpensive adsorbents, and accessible in big amounts, have been suggested to be very effective for the toxic metals removal in the waste water treatments [4].

On the other hand, the purification of water using carbons has been used for ages. Furthermore, the high surface to volume ratio makes activated carbons very attractive for effluent water pollutants removal [5].

Three stages mainly included in the adsorption of contaminants on the surface of porous adsorbents are: ( $I$ ) transport of the solute from the bulk solution to the outward of the adsorbent (diffusion trough film), (ii) intraphase transport to the interior of porous adsorbent (diffusion through porous structure), and (iii) solute uptake on the porous adsorbent surface. It has been considered that the third step of the sorption process is very fast and doesn't have some significant influence on the adsorption kinetics [6]. Usually, the transport of the sorbate to an adsorbent surface is rate influential step in the case of: poor mixing, low sorbate concentration, small pore dimensions of the adsorbent and high affinity of the adsorbent toward adsorbate. Contrary, the systems characte- 
rized with the diffusion trough the adsorbent pores as a limiting step, are distinguished by: high adsorbate concentration, very good mixing, high dimensions of the adsorbent particles, and the low attraction of adsorbate by the adsorbent.

The simple tool for adsorbent evaluation regarding sorbent affinity towards particular solute is adsorption isotherm [7]. Usually, the equilibrium isotherms encountered in the literature are the Langmuir, Freundlich, and Redlich-Paterson isotherms, and many others, although the last one has not found a wide practical application due to the difficulties in the determination of the isotherm constants. It was shown [8] that the adsorption data of $\mathrm{Ni}^{2+}, \mathrm{Cu}^{2+}, \mathrm{Pb}^{2+}$ and $\mathrm{Cd}^{2+}$ at lower concentrations on clinoptilotite shows better agreement to the Freundlich isotherm, while the Langmuir model better describe the adsorption equilibrium at the higher concentrations. On the other hand, some of the researchers have shown that the affinity of the adsorbent for pollutant removal in the batch conditions depends on the $\mathrm{pH}$, concentration of the solutions, the quantity and the size of the adsorbent, the temperature, as well as the rate of mixing [8].

The studies including analyses of kinetics in the effluent water management provides evidence about the paths and mechanisms of the adsorption process, as well as the uptake rate of the solute and mass transfer resistance at the solid-solution interface. Data gathered in the studies of the equilibrium, kinetics and the dynamics of the system in batch settlement are appreciated for the development of the accurate mathematical models necessary for the design optimization of the fixed bed columns used in the industrial adsorption processes.

Researchers have different approach in the definition of the adsorption kinetics of heavy metals on particular adsorbents using both, reaction and diffusion models. Thus, the adsorption of $\mathrm{Zn}^{2+}$ on natural adsorbents demonstrates a pretty good agreement to the pseudo-first reaction model and diffusion model suggesting sorption on the sorbent surface [9]. Experimental and modeling studies of $\mathrm{Zn}^{2+}$ adsorption by granular activated carbon and natural zeolite performed by Meshko et al. taking into consideration two surface reaction equations, second order reversible and second order irreversible reaction models, showed that it is not easy to draw a general conclusion about the suitability of one of the models [10]. Kinetic models based on parabolic diffusion model and Vermeulens' approximation have been applied by the same authors for description of the adsorption behavior of $\mathrm{Zn}^{2+}, \mathrm{Cd}^{2+}$, and $\mathrm{Pb}^{2+}$ on natural zeolite [11].

The objective of this work is to screen and evaluate the effect of initial concentration of lead ions in aqueous solution and adsorbent particle quantity on metal adsorption by granular activated carbon in agitated batch adsorber. The adsorption isotherms parameters, as well as the kinetic models including first, pseudo-first, second and the pseudo-second-order reaction models, for the best fit of our experimentally obtained data were determined using MatLab software.

\section{EXPERIMENTAL}

Solutions of $\mathrm{Pb}^{2+}$ ions were prepared by dissolving $\mathrm{Pb}\left(\mathrm{NO}_{3}\right)_{2}$ (Merck, Germany) in distilled water. The initial concentrations of metal ion used in the adsorption equilibrium experiments varied between 50 and $500 \mathrm{mg} \mathrm{dm}^{-3}$, and it was measured by atomic absorption spectrometer (Vista-MPX CCD Simultaneous ICP-OES).

Granular activated carbon (GAC), which is a carbonized coconut shell activated by water steam was purchased from TRAYAL Corporation, Serbia. This type of activated carbon has been already used in systems for water filtration, and it was also used as adsorbent in our studied systems. GAC was previously washed with deionized water for several times to remove any leachable impurities and adherent powder and then dried to constant weight at $110^{\circ} \mathrm{C}$ for 24 hours. Characterization of GAC by X-ray diffraction and energy dispersive $X$ ray spectroscopy (EDX) [12], have already shown the amorphous nature of the material, and the element composition, given in wt\%, as follows: C$87.67 \%$, O- $11.31 \%$, Si-0.25\%, S-0.09\%, K-0.41\%, and Ca-0.28\%. FTIR spectra [12] have not indicated a presence of surface water in GAC.

Table 1 - Physical properties of granular activated carbon (GAC)

\begin{tabular}{|c|c|c|c|c|c|c|}
\hline $\begin{array}{c}\text { Particle size } \\
(\mathrm{mm})\end{array}$ & $\begin{array}{c}\text { Bulk density } \\
\left(\mathrm{g} \mathrm{cm}^{-3}\right)\end{array}$ & $\begin{array}{c}\text { BET area } \\
\left(\mathrm{m}^{2} \mathrm{~g}^{-1}\right)\end{array}$ & $\begin{array}{c}\text { Pore volume } \\
\left(\mathrm{cm}^{3} \mathrm{~g}^{-1}\right)\end{array}$ & $\begin{array}{c}\text { Micropore volume } \\
\left(\mathrm{cm}^{3} \mathrm{~g}^{-1}\right)\end{array}$ & $\begin{array}{c}\text { lodine number } \\
\text { AWWA } \\
\left(\mathrm{mg} \mathrm{g}^{-1}\right)\end{array}$ & $\begin{array}{c}\text { Ash } \\
\text { content } \\
(\%)\end{array}$ \\
\hline $0.5-1.6$ & $0.44-.48$ & 1200 & $0.8-1.0$ & $0.45-0.50$ & $1150-1250$ & $3-5$ \\
\hline
\end{tabular}

Physical properties of granular activated carbon are given in Table 1.

For the determination of adsorption isotherms a constant mass of adsorbent ( $3 \mathrm{~g}$ granular activated carbon) and $0.2 \mathrm{dm}^{3}$ of distilled water $\mathrm{Pb}^{2+}$ solution of a known initial concentration $\left(50-250 \mathrm{mg} \mathrm{dm}^{-3}\right)$ were agitated in a shaker-bath $(500 \mathrm{rpm})$ at a constant temperature $\left(25^{\circ} \mathrm{C}\right)$ for maximum 12 days 
to guarantee the establishment of an adsorption equilibrium.

Kinetic studies were performed in a batch agitated reactor at constant $\mathrm{pH}$ values containing varying initial metal concentration $50-250 \mathrm{mg} \mathrm{dm}^{-3}$ and constant adsorbent mass of $3 \mathrm{~g}$, as well as, different mass of activated carbon and constant concentration of lead ions of $50 \mathrm{mg} \mathrm{dm}^{-3}$.

The parameters of the both, isotherm and kinetics models were determined applying MatLab software.

\section{RESULTS AND DISCUSSION}

\subsection{Adsorption isotherms}

The opportunity of removal of impurities from the waste water by sorption process is influenced by the adsorption capacity of the adsorbent used. So, usually the first step in the analysis of the adsorption is determination of isotherm which shows the best correlation to the experimental values and assessment of the isotherm parameters. In this study the equilibrium data were modelled to the Langmuir, Eq. 1, and Freundlich isotherms Eq. 2, using MatLab Curve Fitting Tool with a nonlinear least squares. A comparison of experimentally obtained and calculated data using
Langmuir and Freundlich equations are presented in Fig. 1, while the corresponding parameters are given in the Table 2.

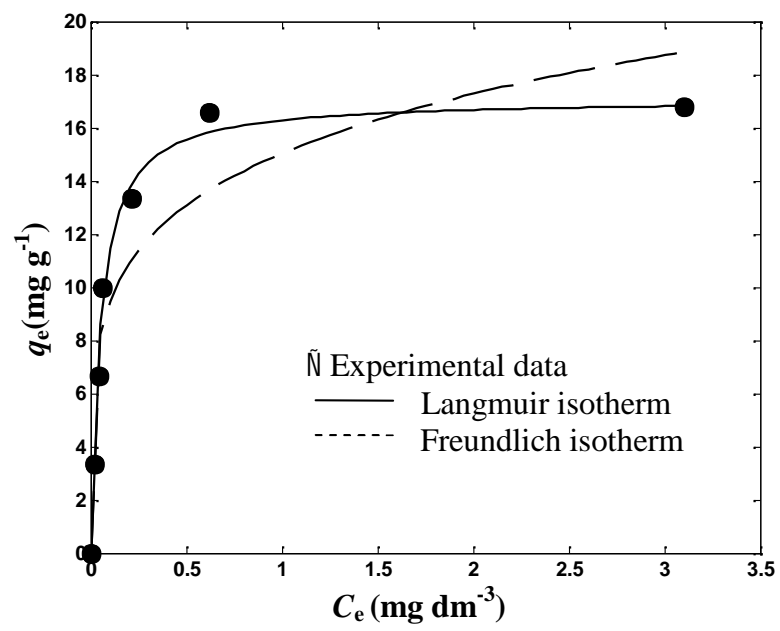

Figure 1 - Comparison of experimentally obtained and calculated data by Langmuir and Freundlich equilibrium isotherms for the system $\mathrm{Pb}^{2+}$. activated carbon

Table 2 - Parameters in the equilibrium isotherms for the system $\mathrm{Pb}^{2+}$ - GAC

\begin{tabular}{|c|c|c|c|c|c|}
\hline \multicolumn{3}{|c|}{ Langmuir isotherm } & \multicolumn{3}{c|}{ Freundlich isotherm } \\
\hline$b\left(\mathrm{dm}^{3} \mathrm{mg}^{-1}\right)$ & $Q_{0}\left(\mathrm{mg} \mathrm{g}^{-1}\right)$ & $R^{2}$ & $K_{\mathrm{F}}\left[\left(\mathrm{mg} \mathrm{g}^{-1}\right)\left(\mathrm{dm}^{3} \mathrm{mg}^{-1}\right)^{1 / n}\right]$ & $n$ & $R^{2}$ \\
\hline 20.429 & 17.085 & 0.9992 & 15.04 & 4.992 & 0.8585 \\
\hline
\end{tabular}

$$
q_{e}=\frac{Q_{0} \cdot b \cdot C_{e}}{\left(1+b \cdot C_{e}\right)}
$$

where: $C_{\mathrm{e}}\left(\mathrm{mg} \mathrm{dm}^{-3}\right)$ the concentration of metal ions at equilibrium; $q_{\mathrm{e}}\left(\mathrm{mg} \mathrm{g}^{-1}\right)$ the amount of adsorbed metal ions at equilibrium calculated by the equation: $q_{e}=\frac{V}{m}\left(C_{0}-C_{e}\right) ; Q_{0}\left(\mathrm{mg} \mathrm{g}^{-1}\right)$ is the maximum sorption capacity; $b\left(\mathrm{dm}^{3} \mathrm{mg}^{-1}\right)$ is an "affinity" parameter, $V\left(\mathrm{dm}^{3}\right)$ is a solution volume, $C_{0}\left(\mathrm{mg} \mathrm{dm}^{-3}\right)$ initial concentration of the metal ions, $m(g)$ mass of the adsorbent (granular activated carbon).

$$
q_{e}=K_{F} \cdot C_{e}^{\frac{1}{n}}
$$

where: $q_{\mathrm{e}}$ and $C_{\mathrm{e}}$ have the same meaning as in Langmuir equation, while $K_{\mathrm{F}}\left[\left(\mathrm{mg} \mathrm{g}^{-1}\right)\left(\mathrm{dm}^{3} \mathrm{mg}^{-1}\right)^{1 / n}\right]$ is a constant related to sorption capacity and $n$ is a constant related to sorption intensity.

The Langmuir model assumes that all the adsorption sites are equally available for adsorption, the adsorbed species doesn't interact and a monolayer is formed during adsorption, whereas the Freudlich isotherm suggests the heterogeneity of the places available for adsorption and could be used at lower and intermediate concentrations of the adsorbate [13].

The trend of the theoretical curves obtained by the Langmuir and Freudlich isotherms in respect to the experimentally obtained value, Fig. 1, as well as the values of the coefficient of determination, $R^{2}$, for the both isotherms, Table 2, clearly indicate the better correspondence of the Langmuir equation in the whole concentration range.

\subsection{Sorption kinetics}

The effect of different adsorbent mass and initial adsorbate concentration on the adsorption kinetics has been assessed in the current analysis, using batch set up with constant agitation speed of $500 \mathrm{rpm}$, at constant temperature of $25^{\circ} \mathrm{C}$ and constant $\mathrm{pH}$ of the system.

\subsubsection{Effect of mass of the adsorbent}

The influence of a mass of granular activated carbon on the quantity of the adsorbed lead ions onto granular activated carbon were studied using different amount of GAC quantity ( 3,5 and $10 \mathrm{~g})$, a constant concentration of lead ions of $50 \mathrm{mg} \mathrm{dm}^{-3}$ 
in the effluent, agitation speed of $500 \mathrm{rpm}$, at temperature of $25^{\circ} \mathrm{C}$. The effect of the the variation of the amount of an adsorbent is given in the Figs $2 \mathrm{a}$ and $2 \mathrm{~b}$. As it can be seen in the first $20 \mathrm{~min}$ there is a quick adsorption of lead ions on GAC for the three cases, after which the adsorption rate becomes constant. Furthermore, as the adsorbent quantity increased, the amount of the sorbed metal per unit mass of the adsorbent decreases, which could be ascribed to the residual unsaturated adsorption sites [14]. Mouni et al., [15] showed growth in the rate of metal ions adsorption as the adsorbent amount in the system increases, apparently as a result of the higher number of active sites. But, for a particular initial metal concentration the additional rise of the adsorbent quantity has not shown significant effect of metal removal rate most probably as a result of overlapping of adsorption sites due to overcrowding of adsorbent particles. Similarly, in our study, Table 3 , the percentage of the removed ions, after the achievement of the equilibrium, has not displayed any significant changes with the increased dosage of GAC in the system from 3 to $10 \mathrm{~g}$. Hence our further analysis has been carried out at constant amount of adsorbent of $3 \mathrm{~g}$ and diverse initial concentrations of metal cation.

Table $3-\mathrm{Pb}^{2+}$ ions uptake at equilibrium, $t=360 \mathrm{~min}$, for different quantity of GAC (initial concentration of adsorbate is constant at $50 \mathrm{mg} \mathrm{dm}^{-3}$ ) and varying initial concentrations of the adsorbate (at constant mass of the adsorbent of $3 \mathrm{~g}$ ); agitation speed of $500 \mathrm{rpm}, T=25^{\circ} \mathrm{C}$

\begin{tabular}{|c|c|c|c|c|c|c|c|c|}
\hline & \multicolumn{3}{|c|}{$\mathbf{m}_{\mathrm{GAC}} \mathbf{( g )}$} & \multicolumn{5}{c|}{$\mathbf{C}_{\mathbf{0}}\left(\mathbf{m g ~ d m}^{-3}\right)$} \\
\hline & 3 & 5 & 10 & 50 & 100 & 150 & 200 & 250 \\
\hline$\% \mathbf{R}$ & 98.6 & 96.8 & 97.9 & 98.6 & 99.7 & 99.8 & 99.8 & 99.5 \\
\hline
\end{tabular}
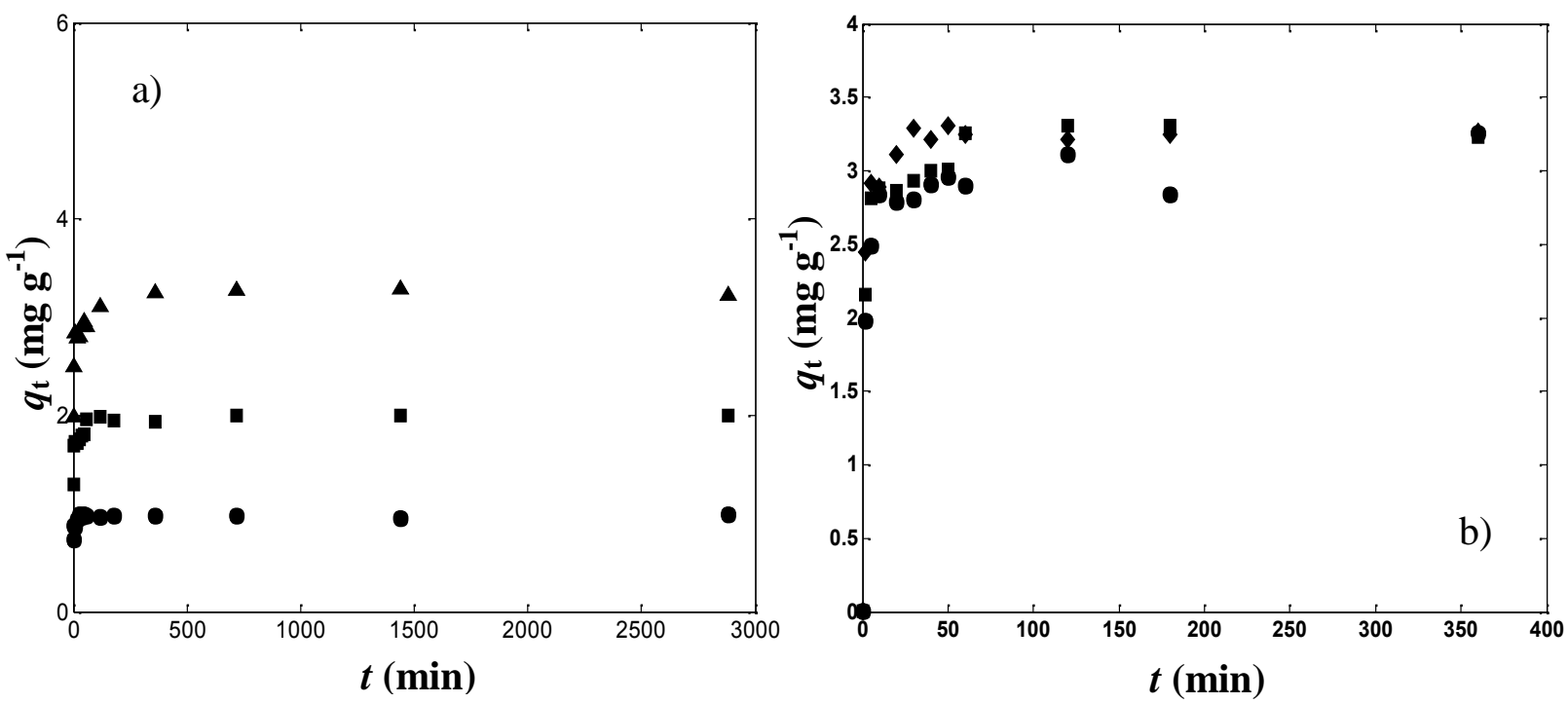

Figures $2 a$ and $2 b$ - Effect of mass of the adsorbent on the quantity of the adsorbed $\mathrm{Pb}^{2+}$ ions by GAC, (500 rpm, $\left.C_{0}=50 \mathrm{mg} \mathrm{dm}{ }^{-3}, T=25^{\circ} \mathrm{C}\right)$; (a) whole period , (b) period 0-360 min;

$$
m=3 g, \quad m=5 g, \bullet m=10 \mathrm{~g}
$$

\subsubsection{Effect of initial concentration}

Determination of the impact of the initial concentration of lead ions on the sorption kinetics denotes a big significance taking into account that the fixed mass of adsorbent may accept only a limitted quantity of the adsorbate.

Dependance of the sorption of lead ions on their initial concentration in the solution shown in Figs. $3 a$ and $3 b$ draw attention to the first part of the curves, Fig. 3b, coresponding to the lower concentrations (50 and $100 \mathrm{mg} \mathrm{dm}^{-3}$ ) of $\mathrm{Pb}^{2+}$ ions in the solution, which practically overlap with the ordinate axis, reaching the equilibrium amount of adsorbed ions in the first $20 \mathrm{~min}$.

As the initial solution concentration increases, the time for accomplishment of the equilibrium increases. Thus for the initial concentration of 150 $\mathrm{mg} \mathrm{dm}$ the time for achivement of the maximum adsorbed quantity is $120 \mathrm{~min}$, while for the concentrations of 200 and $250 \mathrm{mg} \mathrm{dm}^{-3}$ this time increases to the value of around $360 \mathrm{~min}$. 

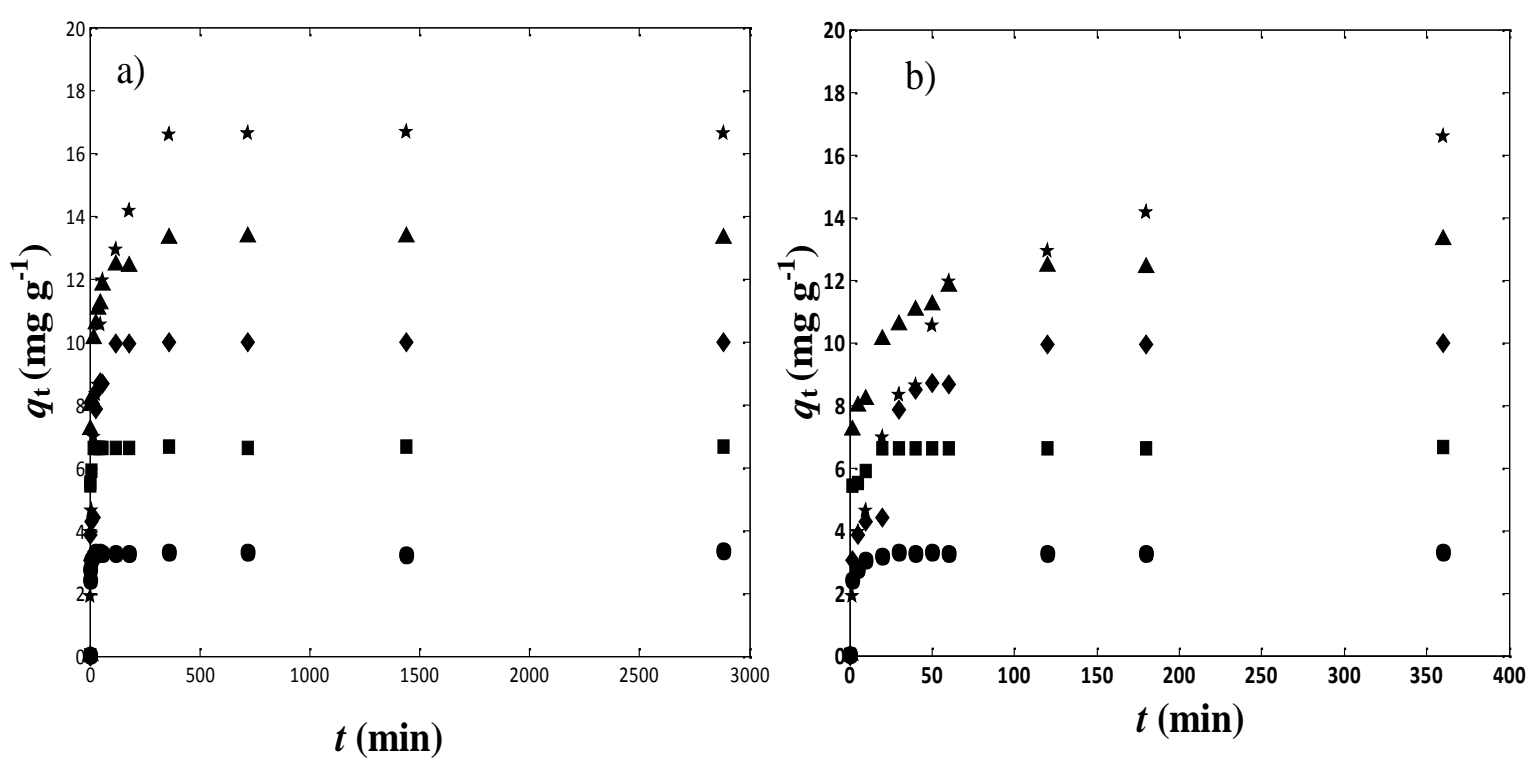

Figures $3 a$ and $3 b$ - Effect of initial concentration on the quantity of the adsorbed $\mathrm{Pb}^{2+}$ ions by GAC (500 rpm; $\left.m_{G A C}=3 \mathrm{~g} ; \mathrm{T}=25^{\circ} \mathrm{C}\right) ; \bullet C_{0}=50 \mathrm{mg} \mathrm{dm}{ }^{-3}, \quad C_{0}=100 \mathrm{mgdm}^{-3}, C_{0}=150 \mathrm{mg} \mathrm{dm}^{-3}, \quad C_{0}=200 \mathrm{mg} \mathrm{dm}^{-3}$, $\star C_{0}=250 \mathrm{mg} \mathrm{dm^{-3 }}$

\section{3,2,3 Modelling of adsorption kinetics}

As it was previously mentioned, the selection of a model which is the most suitable for given data is very difficult. On the other hand, a study of the uptake kinetics of the toxic species by the sorbent has been considered as the basis in the design of the adsorption column in the industrial arrangements.

In order to determine the controlling mechanism of adsorption processes first, second, pseudo-first, and pseudo-second-order models have been used to model the kinetics of lead adsorption on granular activated carbon [16, 17], taking into consideration the effect of the initial concentration of the solute and the adsorbent mass used in the system. Computation of the kinetics parameters in each of the models has been performed using MatLab software.

\section{Simple first and second order rate equations}

The lead ions adsorption kinetics might be explained by a simple first order equation, Eq.3. $[18,19]$ taking into consideration the influence of the initial lead concentration and different adsorbent dosage in the system.

$$
-\frac{d C_{t}}{d t}=k_{1} \cdot C_{0}
$$

After the boundary conditions $t=0, C=C_{0}$ and at $t=t, C=C_{\mathrm{t}}$, were applied, the linear form of the simple first order equation takes the following form:

$$
\ln \left(C_{t}\right)=\log \left(C_{0}\right)-k_{1} \cdot t
$$

where, $C_{\mathrm{t}}\left(\mathrm{mg} \mathrm{dm}^{-3}\right)$ is the concentration of lead ions at time $t, C_{0}\left(\mathrm{mg} \mathrm{dm}^{-3}\right)$ is the initial lead concentration, and $k_{1}\left(\mathrm{~min}^{-1}\right)$ is the first order rate constant.

Rate constant, $k_{1}$, has been determined by plotting the $\log C_{\mathrm{t}}$ versus t, Figs. 4 and 5 . The simple first order kinetics model did not show very good agreement with our experimental data for the whole contact time range in both, different initial concentrations of metal ion, and diverse adsorbent amount, as well.

Therefore multiple first order kinetics has been applied, where a plot $\log C_{\mathrm{t}} / \mathrm{t}$ has been divided in two linear parts [20], Figs. 4 and 5, and the kinetics parameters for different experimental conditions are given in Table 4 .

The higher values of the rate constants in the initial stage of sorption, as well as the Figs. 4 and 5 , indicate faster uptake of ions in the first than in the second period, which is the most probably the result of the sorption where there are not such species existing on the surface, ensuing a monolayer formation. 

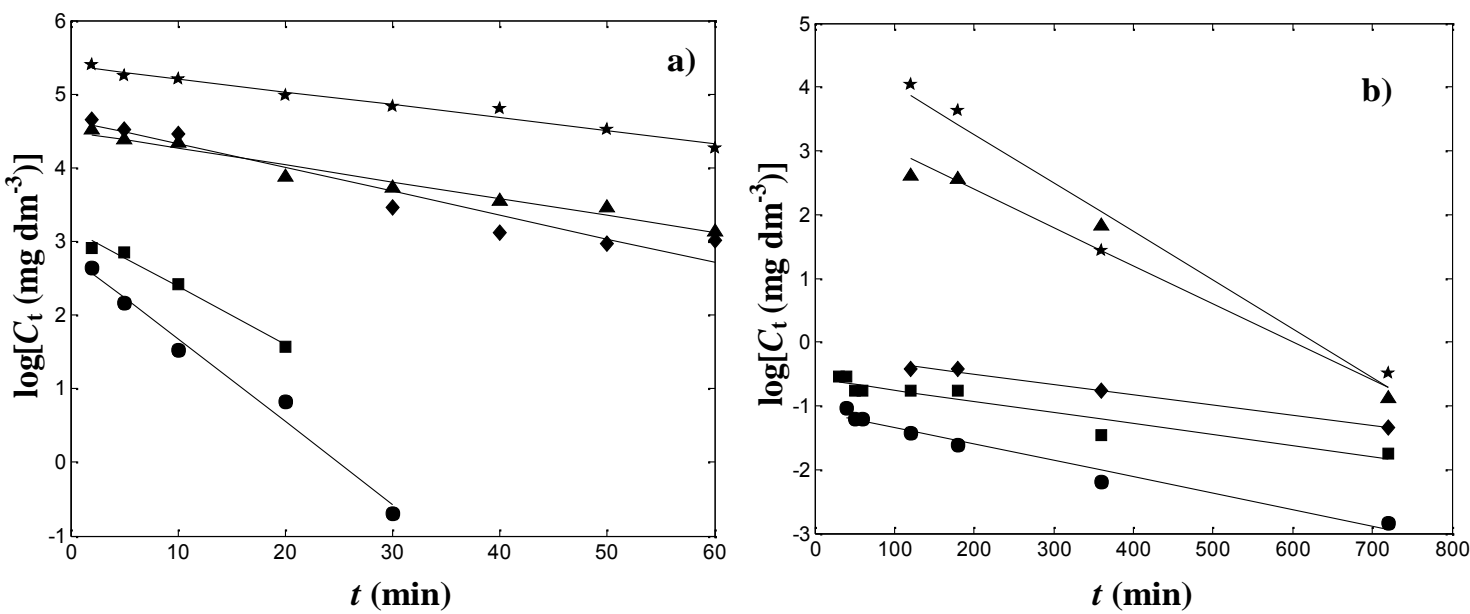

Figures 4 - First order reaction kinetics for the system $P b^{2+}-G A C\left(500 \mathrm{rpm} ; m_{G A C}=3 \mathrm{~g} ; T=25^{\circ} \mathrm{C}\right)$;

(a) period 0-60 min, (b) period 60-720 min; $\bullet C_{0}=50 \mathrm{mg} \mathrm{dm}^{-3}, C_{0}=100 \mathrm{mg} \mathrm{dm}^{-3}, \bullet C_{0}=150 \mathrm{mg} \mathrm{dm}^{-3}$, $C_{0}=200 \mathrm{mg} \mathrm{dm}^{-3}, \star C_{0}=250 \mathrm{mg} \mathrm{dm}^{-3}$; - theoretical
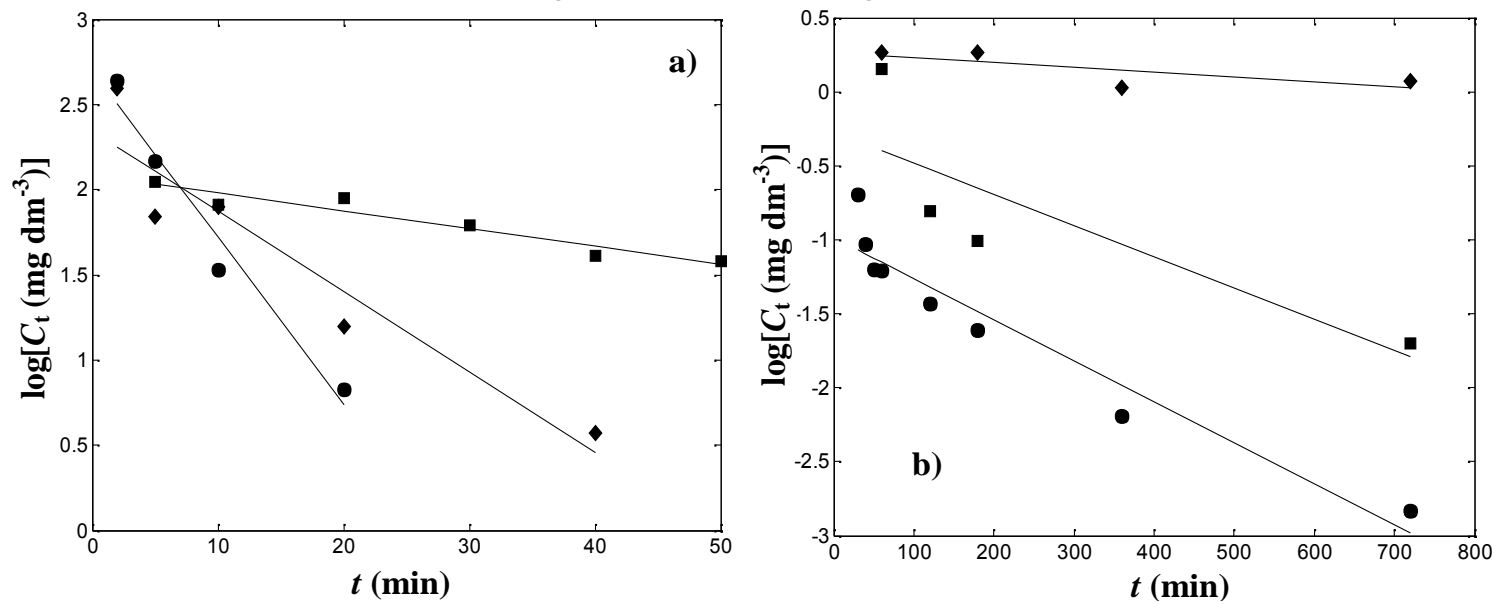

Figures 5 - First order reaction kinetics for the system $\mathrm{Pb}^{2+}-\mathrm{GAC}\left(500 \mathrm{rpm} ; \mathrm{C}_{0}=50 \mathrm{mg} \mathrm{dm^{-3 }} ; \mathrm{T}=25^{\circ} \mathrm{C}\right.$ );

(a) period 0-60 $\mathrm{min}$, (b) period 60-720 $\mathrm{min} ; \bullet \mathrm{m}=3 \mathrm{~g}, \quad \mathrm{~m}=5 \mathrm{~g}, \bullet \quad m=10 \mathrm{~g}$; - theoretical

Table 4 - Kinetics parameters of the sorption of lead ions onto GAC for the first and the second order reactions at different experimental conditions; agitation speed of $500 \mathrm{rpm}, T=25^{\circ} \mathrm{C}$

\begin{tabular}{|c|c|c|c|c|}
\hline & \multicolumn{2}{|c|}{ First order kinetics model } & \multicolumn{2}{|c|}{ Second order kinetics model } \\
\hline $\mathrm{C}_{0}\left(\mathrm{mg} \mathrm{dm}^{-3}\right)^{*}$ & $\mathrm{k}_{1}\left(\mathrm{~min}^{-1}\right)$ & $\mathrm{R}^{2}$ & $\mathrm{k}_{2}\left(\mathrm{dm}^{3} \mathrm{mg}^{-1} \mathrm{~min}^{-1}\right)$ & $\mathrm{R}^{2}$ \\
\hline 50 & $\begin{array}{c}0.11230 \\
(0.002557)\end{array}$ & $\begin{array}{c}0.9822 \\
(0.9705)\end{array}$ & $\begin{array}{c}0.02070 \\
(0.02082)\end{array}$ & $\begin{array}{c}0.9964 \\
(0.9943)\end{array}$ \\
\hline 100 & $\begin{array}{c}0.07808 \\
(0.001752)\end{array}$ & $\begin{array}{c}0.9839 \\
(0.9080)\end{array}$ & $\begin{array}{c}0.01952 \\
(0.005943)\end{array}$ & $\begin{array}{c}0.9462 \\
(0.9490)\end{array}$ \\
\hline 150 & $\begin{array}{c}0.03223 \\
(0.001595)\end{array}$ & $\begin{array}{c}0.9385 \\
(0.9915)\end{array}$ & $\begin{array}{c}0.007101 \\
(0.003953)\end{array}$ & $\begin{array}{c}0.9584 \\
(0.9832)\end{array}$ \\
\hline 200 & $\begin{array}{c}0.02287 \\
(0.005989)\end{array}$ & $\begin{array}{c}0.9666 \\
(0.9689)\end{array}$ & $\begin{array}{c}0.009111 \\
(0.003998)\end{array}$ & $\begin{array}{c}0.9635 \\
(0.8803)\end{array}$ \\
\hline 250 & $\begin{array}{c}0.01762 \\
(0.007629)\end{array}$ & $\begin{array}{c}0.9748 \\
(0.9635)\end{array}$ & $\begin{array}{l}0.0001443 \\
(0.002766)\end{array}$ & $\begin{array}{c}0.9325 \\
(0.9338)\end{array}$ \\
\hline$m_{\text {GAC }}(g)$ & $\mathrm{k}_{1}\left(\min ^{-1}\right)$ & $\mathrm{R}^{2}$ & $\mathrm{k}_{2}\left(\mathrm{dm}^{3} \mathrm{mg}^{-1} \mathrm{~min}^{-1}\right)$ & $\mathrm{R}^{2}$ \\
\hline 3 & $\begin{array}{c}0.09816 \\
(0.00277)\end{array}$ & $\begin{array}{c}0.9655 \\
(0.9255)\end{array}$ & $\begin{array}{c}0.02070 \\
(0.02082)\end{array}$ & $\begin{array}{c}0.9964 \\
(0.9943)\end{array}$ \\
\hline 5 & $\begin{array}{c}0.01046 \\
(0.00211)\end{array}$ & $\begin{array}{c}0.9208 \\
(0.7040)\end{array}$ & $\begin{array}{c}0.001746 \\
(0.006128)\end{array}$ & $\begin{array}{c}0.9203 \\
(0.9278)\end{array}$ \\
\hline 10 & $\begin{array}{c}0.04720 \\
\left(3.334 \cdot 10^{-4}\right)\end{array}$ & $\begin{array}{c}0.8956 \\
(0.5903)\end{array}$ & $\begin{array}{c}0.0125 \\
(0.0002835)\end{array}$ & $\begin{array}{c}0.9821 \\
(0.5767)\end{array}$ \\
\hline
\end{tabular}

The upper values in the cells concern the first period $(0-60 \mathrm{~min})$, while the bottom values in the parenthesis refer the second period (60-720 min).

Experiments performed at different initial metal concentrations, but fixed mass of an absorbent $\left(\mathrm{m}_{\mathrm{GAC}}=3 \mathrm{~g}\right)$

"Experiments performed at different amounts of the adsorbent, and fixed metal concentration of $50 \mathrm{mg} \mathrm{dm}^{-3}$ 
After saturation of the adsorbent surface with metal ions, a second stage occurs, which is actually a process of rearrangement with additional increase in the ions quantity on the adsorbent's surface. The first order kinetics models showed better agreement to the experimental data gathered at different initial concentration of adsorbate, and for the data in the initial adsorption period.

Guided by the idea to present the whole range of ion adsorption on granular activated carbon, it has been assumed that the experimental data might be correlated to the simple second order

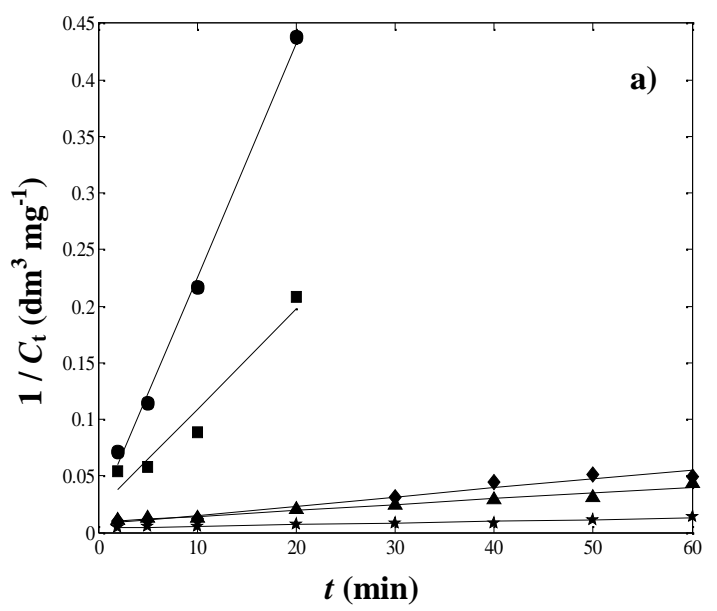

kinetics equation, Eq. 5. As it has been previously suggested, a second order rate equation suggests chemisorption of pollutants by ion exchange reactions [21]. Once the boundary conditions has been applied to Eq.5, $t=0, C=C_{0}$ and at $t=t, C=$ $C_{\mathrm{t}}$, it is transformed in its' linear shape, Eq.6.

$$
\begin{aligned}
& \frac{d C}{d t}=k_{2} \cdot\left[C_{t}\right]^{2} \\
& \frac{1}{\left[C_{t}\right]}=k_{2} \cdot t+\frac{1}{\left[C_{0}\right]}
\end{aligned}
$$

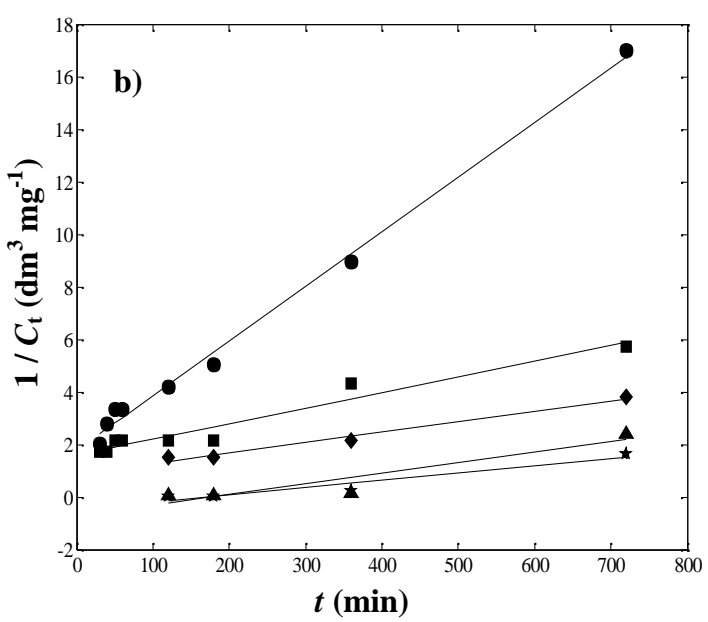

Figure 6 - Second order reaction kinetics for the system $\mathrm{Pb}^{2+}-\mathrm{GAC}\left(500 \mathrm{rpm} ; \mathrm{m}_{\mathrm{GAC}}=3 \mathrm{~g} ; \mathrm{T}=25^{\circ} \mathrm{C}\right)$; (a) period 0-60 min, (b) period 60-720 min; $\bullet C_{0}=50 \mathrm{mg} \mathrm{dm}^{-3}, C_{0}=100 \mathrm{mg} \mathrm{dm}^{-3}, \bullet C_{0}=150 \mathrm{mg} \mathrm{dm}^{-3}$, $C_{0}=200 \mathrm{mg} \mathrm{dm}^{-3}, \star C_{0}=250 \mathrm{mg} \mathrm{dm^{-3 }} ;$ - theoretical
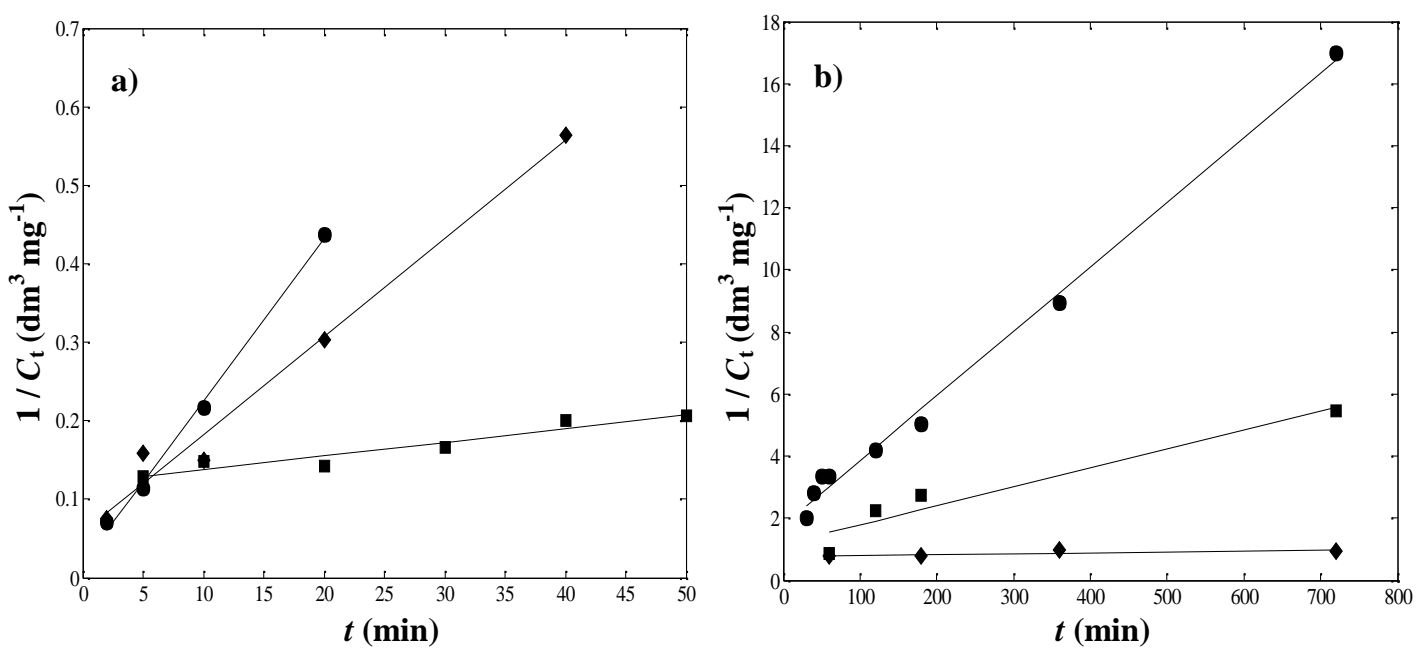

Figure 7 - Second order reaction kinetics for the system $\mathrm{Pb}^{2+}$ - GAC (500 rpm; $C_{0}=50 \mathrm{mg} \mathrm{dm^{-3 }}$; $T=25^{\circ} \mathrm{C}$ ); (a) period 0-50 $\mathrm{min}$, (b) period 50-720 $\mathrm{min} ; \bullet \mathrm{m}=3 \mathrm{~g}, \quad \mathrm{~m}=5 \mathrm{~g}, \bullet \mathrm{m}=10 \mathrm{~g}$; - theoretical

where $C_{\mathrm{t}}\left(\mathrm{mg} \mathrm{dm}^{-3}\right)$ is the concentration of metal ions at equilibrium, $C_{0}\left(\mathrm{mg} \mathrm{dm}^{-3}\right)$, the initial concentration of metal ions, $t$, the time ( $\mathrm{min})$, and $k_{2}$ is the rate constant $\left(\mathrm{dm}^{3} \mathrm{mg}^{-1} \mathrm{~min}^{-1}\right)$.
Second order kinetic plots displaying in parallel the experimental values and the fitted data presented as straight lines, found by the MatLab software, for different initial concentration of $\mathrm{Pb}^{2+}$ ions and different quantity of the adsorbent, are 
shown in Figs. 6 and 7, and Table 4. As in the case of the first kinetics equation, the second kinetics model couldn't be fitted to the experimental data in the whole period of adsorption process. Consequently, a multiple second order kinetics has been suggested by splitting the whole range into two portions, which indicate a two process occurring. The slope of the dependences $\left(1 / C_{t}\right) / t$, Figs. 6 and 7 , as well as the data for the rate constant in the Table 4, did not indicate a significantly faster initial adsorption than the second process of reorganization of the adsorbed spices. The values of $R^{2}$ also designate the deficiency in the expression of adsorption process by simple second order models, especially for higher values the initial concentration of lead ions, higher quantity of adsorbent.

Granular activated carbon contains functional groups which could be involved in a chemical bonding (chemisorption), and also are considered as responsible for the creation of chemical bonds between the active spices of GAC and divalent metal cations, such as $\mathrm{Pb}^{2+}$ [22]. Thus, in the further analysis the models based on adsorption capacities instead of solution concentrations were considered, taking into account the pseudo-first and pseudo-second reaction models.

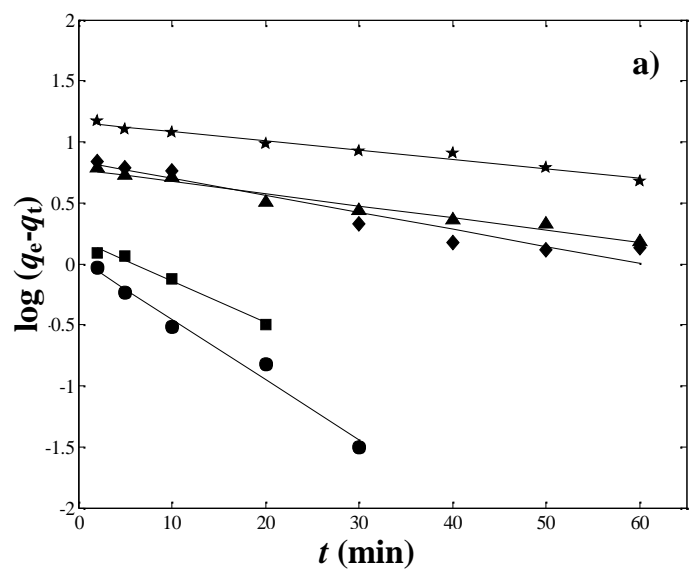

Pseudo-first-order and pseudo-second-order rate equations

Pseudo-first-order, also called Lagergen rate equation, has been the first model based on the capacity of the solid adsorbent applied for the liquid / solid system, and it is presented in Eq. 7.

$$
\frac{d q_{t}}{d t}=k_{p 1} \cdot\left(q_{e}-q_{t}\right)
$$

where, $q_{\mathrm{e}}(\mathrm{mg} / \mathrm{g})$ is the adsorption capacity at equilibrium, $q_{\mathrm{t}}(\mathrm{mg} / \mathrm{g})$ is the adsorption capacity after some time $t(\mathrm{~min}), k_{\mathrm{p} 1}\left(\mathrm{~min}^{-1}\right)$ is the pseudofirst-order rate constant. By the integration of Eq. 7, and applying the boundary conditions: at $t=0, q_{\mathrm{t}}=$ 0 and at $\mathrm{t}=\mathrm{t}, q_{\mathrm{t}}=q_{\mathrm{t}}$ [23], it is yielded the following equation:

$$
\log \left(q_{e}-q_{t}\right)=\log q_{e}-\frac{k_{p 1}}{2.303} t
$$

In order to fit the Eq. 8 to the experimental data, the value of the adsorption capacity at equilibrium should be known. Pseudo-first-order kinetic have a deficiency of representing the adsorption process in the whole time range, so that a two kinetic steps were considered, in the period 0 to $60 \mathrm{~min}$, and 60 to $720 \mathrm{~min}$.

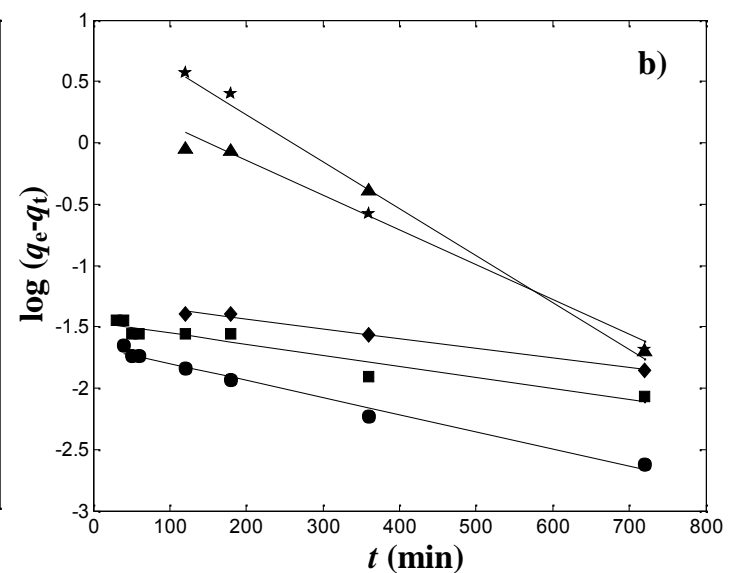

Figure 8 - Pseudo-first-order reaction kinetics for the system $\mathrm{Pb}^{2+}-\mathrm{GAC}\left(500 \mathrm{rpm} ; \mathrm{m}_{\mathrm{GAC}}=3 \mathrm{~g} ; \mathrm{T}=25^{\circ} \mathrm{C}\right)$;

(a) period 0-60min, (b) period 60-720min; $\bullet C_{0}=50 \mathrm{mg} \mathrm{dm}^{-3}, \quad C_{0}=100 \mathrm{mg} \mathrm{dm}^{-3}, \bullet C_{0}=150 \mathrm{mg} \mathrm{dm}^{-3}$, $C_{0}=200 \mathrm{mg} \mathrm{dm}^{-3}$, $\star C_{0}=250 \mathrm{mg} \mathrm{dm}^{-3}$; - theoretical

The experimental values, as well as the fitted models by MatLab software, presented as straight lines, for different experimental conditions are shown in the Figs. 8 and 9, while the corresponding values of the kinetics parameters are given in the Table 5.

As the initial concentration of lead ions increases, in the initial adsorption period, a trend of decreasing of pseudo-first-order rate constants, $k_{p 1}$, has been observed, while for the second period some regularity in the values of $k_{p 1}$ hasn't been noticed. Moreover, some consistency in the values of the rate constant with the increased quantity of activated carbon has not been detected. According to the values of the coefficient of determination $R^{2}$, and Figs. 8 and 9, the experimental data are clustered around the theoretical pseudo-first-order model line for different initial $\mathrm{Pb}^{2+}$ concentrations, but in the case of different adsorbent quantity, those are greatly dissipated. On the contrary, the calculated values of the adsorption capacity at equilibrium show better agreement to the experimental counterpart for different amount of GAC for both periods. Despite the observed results, the fact that the pseudo-first-order kinetics model did not fit the whole range of the experiment, and especially the big divergences in the coefficient of determination of the proposed model to the experimentally data gained for different adsorbent quantity involve a rejection of this model. 

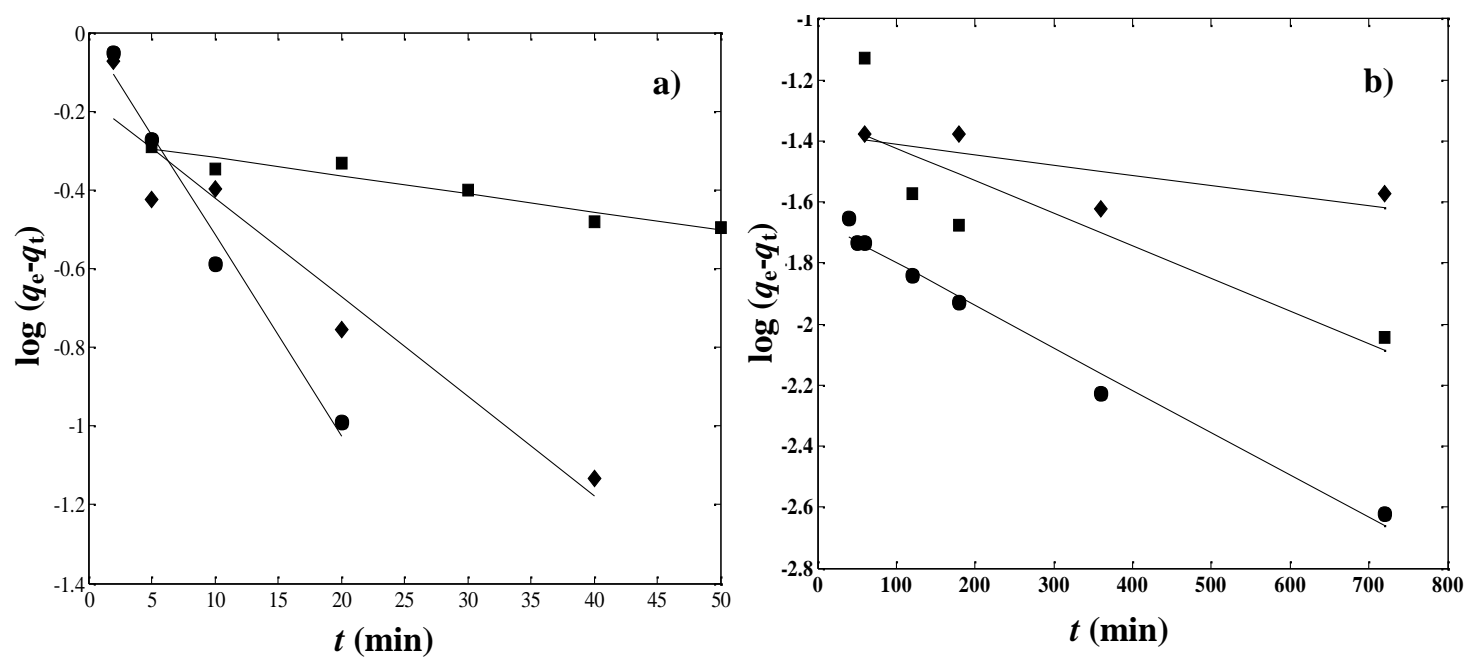

Figure 9 - Pseudo-first-order reaction kinetics for the system $\mathrm{Pb}^{2+}-\mathrm{GAC}\left(500 \mathrm{rpm} ; \mathrm{C}_{0}=50 \mathrm{mg} \mathrm{dm}^{-3}\right.$; $T=25^{\circ} \mathrm{C}$ ); (a) period 0-50 $\mathrm{min}$, (b) period 50-720 $\mathrm{min} ; \bullet \mathrm{m}=3 \mathrm{~g}, \quad \mathrm{~m}=5 \mathrm{~g}, \bullet \mathrm{m}=10 \mathrm{~g}$; - theoretical

Table 5 - Kinetics parameters of the sorption of lead ions onto GAC for pseudo-first-order reaction at different experimental conditions; agitation speed of $500 \mathrm{rpm}, \mathrm{T}=25^{\circ} \mathrm{C}$

\begin{tabular}{|c|c|c|c|c|}
\hline$C_{0}\left(\mathrm{mg} \mathrm{dm}^{-3}\right)^{\star}$ & $k_{p 1}\left(\min ^{-1}\right)$ & $\begin{array}{c}q_{\mathrm{e}}\left(\mathrm{mg} \mathrm{g}^{-1}\right) \\
\text { (exp. obtained) }\end{array}$ & $\begin{array}{c}q_{\mathrm{e}}\left(\mathrm{mg} \mathrm{g}^{-1}\right) \\
\text { (calculated) }\end{array}$ & $\mathbf{R}^{2}$ \\
\hline 50 & $\begin{array}{c}0.1138 \\
(0.003203) \\
\end{array}$ & $\begin{array}{c}3.2910 \\
(3.3203) \\
\end{array}$ & $\begin{array}{c}3.3310 \\
(3.3240) \\
\end{array}$ & $\begin{array}{c}0.9815 \\
(0.9883)\end{array}$ \\
\hline 100 & $\begin{array}{c}0.07851 \\
(0.002081) \\
\end{array}$ & $\begin{array}{c}6.3399 \\
(6.6483) \\
\end{array}$ & $\begin{array}{c}6.6010 \\
(6.6580)\end{array}$ & $\begin{array}{c}0.9838 \\
(0.9179)\end{array}$ \\
\hline 150 & $\begin{array}{c}0.03232 \\
(0.001838) \\
\end{array}$ & $\begin{array}{c}8.7200 \\
(10.0069) \\
\end{array}$ & $\begin{array}{c}10.2900 \\
(10.0200) \\
\end{array}$ & $\begin{array}{c}0.9262 \\
(0.9918) \\
\end{array}$ \\
\hline 200 & $\begin{array}{c}0.02294 \\
(0.006538) \\
\end{array}$ & $\begin{array}{c}11.7887 \\
(13.2813) \\
\end{array}$ & $\begin{array}{c}13.5000 \\
(13.1800)\end{array}$ & $\begin{array}{c}0.9667 \\
(0.9634)\end{array}$ \\
\hline 250 & $\begin{array}{c}0.01767 \\
(0.008813)\end{array}$ & $\begin{array}{c}11.9372 \\
(16.6255) \\
\end{array}$ & $\begin{array}{c}16.5900 \\
(16.1700)\end{array}$ & $\begin{array}{c}0.9748 \\
(0.9830)\end{array}$ \\
\hline$m_{G A C}(g) * *$ & $k_{p 1}\left(\min ^{-1}\right)$ & $\begin{array}{c}q_{\mathrm{e}}\left(\mathrm{mg} \mathrm{g}^{-1}\right) \\
\text { (exp. obtained) }\end{array}$ & $\begin{array}{c}\mathrm{q}_{\mathrm{e}}\left(\mathrm{mg} \mathrm{g}^{-1}\right) \\
\text { (calculated) }\end{array}$ & $\mathbf{R}^{2}$ \\
\hline 3 & $\begin{array}{c}0.1138 \\
(0.003203) \\
\end{array}$ & $\begin{array}{c}3.2910 \\
(3.3203)\end{array}$ & $\begin{array}{c}3.3310 \\
(3.3240)\end{array}$ & $\begin{array}{c}0.9815 \\
(0.9853)\end{array}$ \\
\hline 5 & $\begin{array}{c}0.01054 \\
(0.002454)\end{array}$ & $\begin{array}{c}3.0100 \\
(3.3211)\end{array}$ & $\begin{array}{c}3.3260 \\
(3.3410)\end{array}$ & $\begin{array}{c}0.9208 \\
(0.7410)\end{array}$ \\
\hline 10 & $\begin{array}{c}0.05812 \\
(0.0007804)\end{array}$ & $\begin{array}{c}3.2150 \\
(3.2619)\end{array}$ & $\begin{array}{c}3.3500 \\
(3.2920)\end{array}$ & $\begin{array}{c}0.9263 \\
(0.5696)\end{array}$ \\
\hline
\end{tabular}

The upper values in the cells concern the first period $(0-60 \mathrm{~min})$, while the bottom values in the parenthesis refer the second period (60-720 min).

* Experiments performed at different initial metal cation concentrations, but fixed mass of an absorbent $\left(m_{\mathrm{GAC}}=3 \mathrm{~g}\right)$

** Experiments performed at different amounts of the adsorbent, and fixed metal cation concentration of $50 \mathrm{mg} \mathrm{dm}^{-3}$

In the most of the cases the problem of achievement of equilibrium occurs, since it can be a very long process, so that the value of the adsorption capacity at equilibrium is not known. The application of a pseudo-second-order equation often overcomes that issue, hence, the adsorption capacity at equilibrium and the initial adsorption rate can be calculated directly from the model [21].

In some previous studies [21, 24], the pseudo- second-order model, which also recommends that the interaction between the adsorbent and the adsorbate besides physical includes the chemical interaction involving covalent or ionic forces, has been successfully applied for the adsorption processes of metal ions from the water effluents.

Pseudo-second-order model and its linear form after the boundary conditions (at $t=0, q_{\mathrm{t}}=0$ and $t$ $=t, q_{\mathrm{t}}=q_{\mathrm{t}}$ ) have been applied, are given in the Eq. 9 and Eq.10, respectively. 


$$
\begin{aligned}
& \frac{d q_{t}}{d t}=k_{2}\left(q_{e}-q_{t}\right)^{2} \\
& \frac{1}{q_{t}}=\frac{1}{k_{2} \cdot q_{e}^{2}}+\frac{1}{q_{e}} \cdot t
\end{aligned}
$$

where, $q_{\mathrm{e}}\left(\mathrm{mg} \mathrm{g}^{-1}\right)$ is the amount of the adsorbate at equilibrium, $q_{t}\left(\mathrm{mg} \mathrm{g}^{-1}\right)$ is the amount of adsorbate on the adsorbent surface at any time $t$ $(\min )$, while $k_{2}$ is the adsorption rate constant $(\mathrm{g}$ $\left.\mathrm{mg}^{-1} \min ^{-1}\right)$.

Table 6 - Kinetics parameters of the sorption of lead ions onto GAC for pseudo-second-order reaction rate constants at different experimental conditions; agitation speed of $500 \mathrm{rpm}, T=25^{\circ} \mathrm{C}$

\begin{tabular}{|c|c|c|c|c|c|}
\hline$C_{0}\left(\mathrm{mg} \mathrm{dm}^{-3}\right)^{*}$ & $k_{\mathrm{p} 2}\left(\mathrm{~g} \mathrm{mg}^{-1} \mathrm{~min}^{-1}\right)$ & $\begin{array}{c}q_{\mathrm{e}}\left(\mathrm{mg} \mathrm{g}^{-1}\right) \\
(\text { exp. obtained })\end{array}$ & $\begin{array}{c}q_{\mathrm{e}}\left(\mathrm{mg} \mathrm{g}^{-1}\right) \\
(\text { calculated })\end{array}$ & $h\left(\mathrm{mg} \mathrm{g}^{-1} \mathrm{~min}^{-1}\right)^{(\$)}$ & $R^{2}$ \\
\hline 50 & 0.1003 & 3.3227 & 3.3058 & 1.0961 & 0.9998 \\
\hline 100 & 0.1705 & 6.6569 & 6.6578 & 7.5576 & 1.0000 \\
\hline 150 & 0.0128 & 10.0209 & 10.0594 & 1.2953 & 0.9999 \\
\hline 200 & 0.0116 & 13.3013 & 13.3369 & 2.0633 & 1.0000 \\
\hline 250 & 0.0024 & 16.6460 & 16.8037 & 0.6777 & 0.9998 \\
\hline$m_{\mathrm{GAC}}(\mathrm{g})^{* *}$ & $k_{\mathrm{p} 2}\left(\mathrm{~g} \mathrm{mg}^{-1} \mathrm{~min}^{-1}\right)$ & $\begin{array}{c}q_{\mathrm{e}}\left(\mathrm{mg} \mathrm{g}^{-1}\right) \\
(\text { exper. obtained })\end{array}$ & $\begin{array}{c}q_{\mathrm{e}}\left(\mathrm{mg} \mathrm{g}^{-1}\right) \\
(\text { calculated })\end{array}$ & $h\left(\mathrm{mg} \mathrm{g}^{-1} \mathrm{~min}^{-1}\right)^{(\$)}$ & $R^{2}$ \\
\hline 3 & 0.0847 & 3.2833 & 3.2446 & 0.8913 & 0.9998 \\
\hline 5 & 0.0930 & 3.3302 & 3.3322 & 0.9688 & 1.0000 \\
\hline 10 & 0.1266 & 3.2886 & 3.2712 & 1.3548 & 0.9998 \\
\hline
\end{tabular}

"Experiments performed at different initial metal cation concentrations, but fixed mass of an absorbent $\left(\mathrm{m}_{\mathrm{GAC}}=3 \mathrm{~g}\right)$

${ }^{* *}$ Experiments performed at different amounts of the adsorbent, and fixed metal cation concentration of $50 \mathrm{mg} \mathrm{dm}^{-3}$

${ }^{(\$)} h$ is the initial adsorption rate $\left(\mathrm{mg} \mathrm{g}^{-1} \min ^{-1}\right) ; h=k_{2} \quad q^{2}$

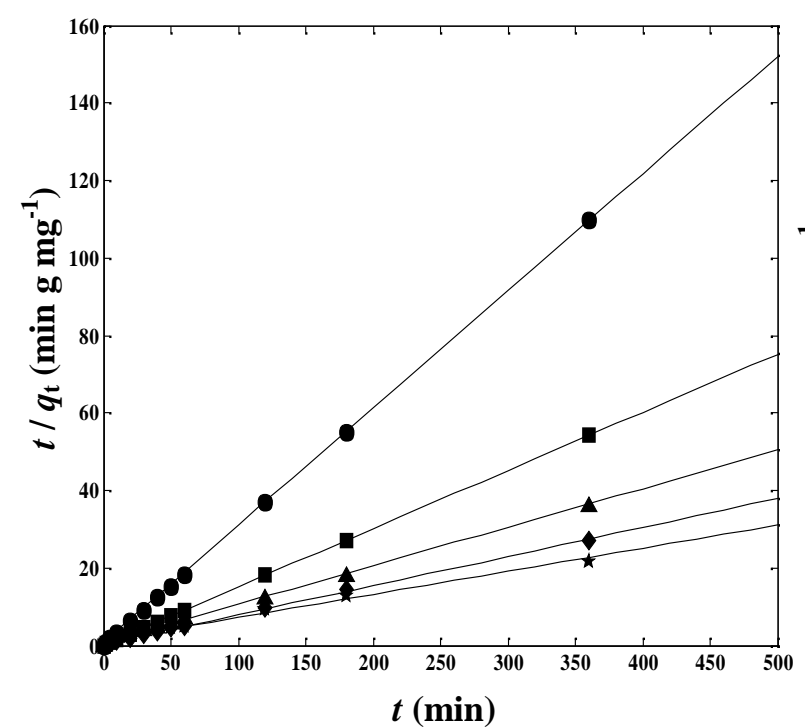

Figure 10 - Pseudo-second-order reaction kinetics for the system $\mathrm{Pb}^{2+}$ - GAC (500 rpm; $m_{G A C}=3 \mathrm{~g} ; \mathrm{T}$ $\left.=25^{\circ} \mathrm{C}\right) ; \bullet C_{0}=50 \mathrm{mg} \mathrm{dm}^{-3}, \quad C_{0}=100 \mathrm{mg} \mathrm{dm}^{-3}$

The parameters of the pseudo-second-order equation fitted to the experimental data, Table 5, have been determined by the MatLab software, for different initial concentration of $\mathrm{Pb}^{2+}$ ions, and diverse amounts of GAC, while the linear dependences $\left(t / q_{t}\right) / t$ of the model are given in the Figs. 10 and 11.

As it can be seen from the Figs 10 and 11, and confirmed by the values of the coefficient of determination, $R^{2}$, between 0.9998 and 1.0 , Table 6 , the pseudo-second-order kinetics equation ex- plains very well a given set of experimental data, for both, different initial lead concentration, and the adsorbent dosage. Furthermore, the values of the quantity of the adsorbed metal ions at the equilibrium obtained experimentally are very close and they are consistent with those calculated [25], using the Curve Fitting Tool of the MatLab software. It can be proposed that the adsorption of $\mathrm{Pb}^{2+}$ ions onto granular activated carbon can be properly defined by the pseudo-second-order adsorption mechanism referring that the adsorption depends on both, adsorbate and the adsorbent, and it is controlled by the chemisorption process.

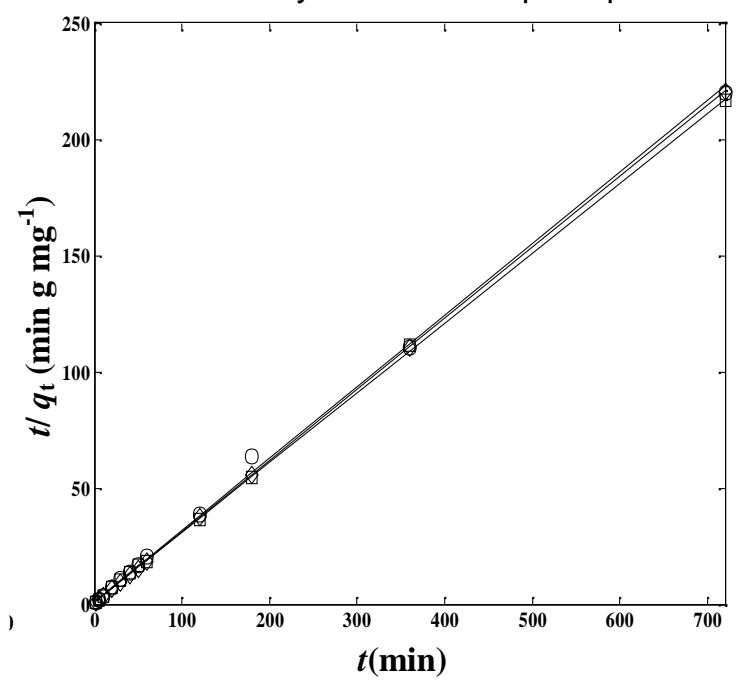

Figure 11 - Pseudo-second-order reaction kinetics plots for the system $\mathrm{Pb}^{2+}-\mathrm{GAC}$ (500 rpm;

$\left.C_{0}=50 \mathrm{mg} \mathrm{dm}^{-3} ; T=25^{\circ} \mathrm{C}\right) ; \circ \mathrm{m}=3 \mathrm{~g}, \quad m=5 \mathrm{~g}$, $\diamond m=10 \mathrm{~g}$; - theoretical 


\section{CONCLUSIONS}

The adsorption study of lead ions onto granular activated carbon has been performed using adsorption batch settlement, at constant temperature, variable initial concentration of the adsorbate $\left(\mathrm{Pb}^{2+}\right)$ and/or different quantities of used adsorbent (GAC).

Two isotherm equations, Langmuir and Freundlich, were used to fit the experimental data at equilibrium. Application of the Langmuir isotherm showed higher coefficients of determination $\left(R^{2} \approx\right.$ 1.0 ), indicating the suitability of this equilibrium model in the whole concentration range of the lead ions.

Four models, namely, first order, second order, pseudo-first-order and pseudo-second-order equations, have been proposed to correlate the kinetics of lead adsorption onto granular activated carbon. The first order, the second order and the pseudofirst-order models could not be correlated to the whole range of experimental data, so that two-step reaction mechanisms were considered. Nevertheless, the values of the determined reaction rate constants for the simple first and second, as well as for the pseudo-first model did not show any regularity when the different experimental conditions were applied. Moreover, the values of the coefficients of determination, especially in the case of different amount of the adsorbent, pointed to the unsuitability of those models accounting sorption process of lead cations.

The best correlation to the experimentally obtained data has been provided by the pseudosecond-order reaction model, designating the chemisorption as a rate determining step during adsorption of $\mathrm{Pb}^{2+}$ ions on granular activated carbon. The initial rates of the adsorption, as well as the quantity of the adsorbed metal on adsorbent surface have been calculated using MatLab Curve Fitting Tool software. It has been observed that the calculated values of the quantity of adsorbed metal at equilibrium match to the experimentally obtained values. Despite the fact that the simplest is the best model, which leads to the selection of the pseudofirst-order kinetics equation in the design of the adsorption units, it should be kept in mind that except the surface reactions the other phenomena, like the mass transfer resistance in the solute-solid interface, as well as the diffusion of the solutes in the pores of the adsorbent should be taken into consideration, which would imply the application of more complex models.

\section{REFERENCES}

[1] D.Lakherwal (2014) Adsorption of Heavy Metals: A Review, International Journal of Environmental Research and Development, 4, 1, 41-48.
[2] K. B. Payne, T. M. Abdel-Fattah (2004) Adsorption of Divalent Lead Ions by Zeolites and Activated Carbon: Effects of $\mathrm{pH}$, Tempe-rature, and Ionic Strength, J. Environ. Sci. Health, Part A, 39, 9, 2275-2291.

[3] Rieman C., Caritat P. (1998): Chemical elements in the environment: fact sheets for the geochemist and environmental scientist, Springer, Berlin.

[4] AIDuri, B. (1996): Introduction to adsorption, In: Use of Adsorbents for the removal of pollutants from wastewaters, Ed.McKey, CRC Press, Boca Raton.

[5] Cooney D. O., (1998): Sorption Design for Wastewater Treatment, Lewis Publishers, Boca Raton.

[6] D. Mohan, K. P. Singh (2002) Single- and multicomponent adsorption of cadmium and zinc using activated carbon derived from bagasse - an agricultural waste, Water Res., 36 9, 2304-2318.

[7] C.K. Jain, D.C. Singhal, M.K. Sharma, (2004) Adsorption of zinc on bed sediment of River Hindon: adsorption models and kinetics, J. Hazard. Mater., B114 (1-3), 231-239.

[8] M. Sprynskyy, B. Buszewski, A. P. Terzyk, J. Namiesnik (2006) Study of the selection mechanism of heavy metal $\left(\mathrm{Pb}^{2+}, \mathrm{Cu}^{2+}, \mathrm{Ni}^{2+}\right.$ and $\left.\mathrm{Cd}^{2+}\right)$ adsorption on clinoptilolite, J. Colloid Interface Sci., 304 1, 21-28.

[9] Y.S. Al-Degs, M.I.El-Barghouthi, A.A. Issa, M.A. Khraisheh, G.M. Walker (2006) Sorption of Zn(II), $\mathrm{Pb}$ (II), and $\mathrm{Co}$ (II) using natural sorbents: Equilibrium and kinetics studies, Water Res., 40, 14, 2645-2658.

[10] V. Meshko, L. Markovska, M. Marinkovski (2006) Experimental study and modelling of zinc adorptionby granular activated carbon and natural zeolite, Int. .J. of Environment and Pollution, 27, 4, 285-299.

[11] J.Taparcevska, L. Markovska, B.Koumanova, V. Meshko (2010) Diffusion models for adsorption kinetics of $\mathrm{Zn}^{2+}, \mathrm{Cd}^{2+}$ and $\mathrm{Pb}^{2+}$ onto natural zeolite, Water Sci. Technol., 62, 5 1136-1142.

[12] M. Minceva, R. Fajgar, L. Markovska, and V. Meshko (2007) Comparative Study of $\mathrm{Zn}^{2+}, \mathrm{Cd}^{2+}$, and $\mathrm{Pb}^{2+}$ removal from water solution using natural clinoptilolitic zeolite and commercial granular activated carbon, Maced. J. Chem. Chem. En., 26, 2, 125-134.

[13] M. Minceva, R. Fajgar, L. Markovska, and V. Meshko (2008) Comparative study of $\mathrm{Zn}^{2+}, \mathrm{Cd}^{2+}$, and $\mathrm{Pb}^{2+}$ removal from water solution using natural clinoptilolitic zeolite and commercial granulated activated Carbon. Equilibrium of Adsorption, Sep. Sci. Technol., 43, 8, 1-27.

[14] Y. Bulut, H. Aydin (2006) A kinetic and thermodynamics study of methylene blue adsorption on wheat shells, Desalination, 194, 1-3, 259-267.

[15] L. Mouni, D. Merabet, A. Bouzaza, L. Belkhiri (2011) Adsorption of $\mathrm{Pb}$ (II) from aqueous solutions using activated carbon developed from Apricot stone, Desalination, 276, 1-3, 148-153.

[16] Kayode Coker A. (2001): Modelling of chemical kinetics and reactor design, Gulf Publishing Company, Houston. 
[17] H. Qiu, L. Lv, B. Pan, Q. Zhang, W. Zhang, Q. Zhang (2009) Journal of Zhejiang University, Science A, 10, 5, 716-724.

[18] M. A. Hossain, M. Kumita, Y Michigami, S. Mori (2005) Kinetics of $\mathrm{Cr}(\mathrm{VI})$ Adsorption on used black tea leaves, Journal of Chemical Engineering of Japan, 38, 6, 402-406.

[19] C.A. Eligwe, N.B. Okolue (1994) Adsorption of iron(II) by a Nigerian brown coal, Fuel, 73, 4, 569572.

[20] Y. S. Ho, G. McKay (1999) The sorption of lead(II) ions on peat, research notes, Water Res., 33, 2, 578-584.

[21] Y.S. Ho (2006) Review of second-order models for adsorption systems, J. Hazard. Mater., B136) 3, 681-689.
[22] Atkins P. W., Walters V., De Paula J. (2006): Physical Chemistry, 8th Edition, Macmillan Higher Education.

[23] Y.S. Ho (2006) Citation review of Lagergren kinetic rate equation on adsorption reactions. Scienometrics, 59, 1, 171-177.

[24] H. Wang, A. Zhou, F. Peng, H. Yu, J. Yang, (2007) Mechanism study on adsorption of acidified multiwalled carbon nanotubes to $\mathrm{Pb}(\mathrm{II}), \mathrm{J}$. Colloid Interface Sci., 316, 2, 277-283.

[25] A.M. El-Wakil, W.M. Abou El-Maaty, F.S. Awad (2014) Removal of lead from aqueous solution on activated carbon and modified activated carbon prepared from dried water hyacinth plan, Journal of Analytical \& Bioanalytical Techniques, 5, 2, 1000187-1000195.

\section{IZVOD}

\section{KINETIČKI MODELI ADSORPCIJE TEŠKIH METALA GRANULIRANIM AKTIVNIM UGLJEM}

Adsorpcija je jedna od najefikasnijih i najekonomičnijih metoda u pročišćavanju otpadnih voda, pri tom granulirani aktivni ugalj je jedan od najkorišćenjijih adsorbensa za teške metale. U ovom je radu ispitivan uticaj količine aktivnog uglja i početne koncentracije olova u rastvoru na kinetiku adsorpcije, pri konstantnoj temperaturi, koristeći šaržni adsrober. Parametri Langmuir-ove $i$ Freundlich-ove adsorpcione izoterme, kao i kinetički modeli za prvi, drugi, pseudo-prvi i pseudodrugi red reakcije su određeni kompjuterskim programom MatLab. Pokazalo se da su Langmuirova izoterma i model pseudo-drugog reda pogodniji ako se u obzir uzme celo eksperimentalno područje.. Maksimalni kapacitet sorpcije je $17.09 \mathrm{mg} \mathrm{g}^{-1}$.

Ključne reči: adsorpcija, sorpcija olova, adsorpcione izoterme, kinetika

Originalni naucni rad

Rad primljen: 04. 02. 2015.

Rad prihvaćen: 25. 03. 2015. 